\title{
建設時の落下物に対する 安全離隔距離に関する研究
}

\author{
山田 貴久 1 - 福重 進也 2 - 降駒 導爵 3 - 鈴木 紀彦 4 \\ 1正会員＼cjkstart東京ガスエンジニアリングソリューションズ侏（†105-0022 東京都港区海岸1-2-3） \\ E-mail: t_yamada@tokyogas-es.co.jp \\ 2非会員 (株IHI（†235-8501 神奈川県横浜市磯子区新中原町1番地） \\ E-mail: shinya_fukushige@ihi.co.jp \\ 3非会員 (株IHI（テ135-8710 東京都江東区豊洲三丁目1番1号 豊洲IHIビル) \\ E-mail:michitaka_furikoma@ihi.co.jp \\ 4非会員 (株IHI（干135-8710 東京都江東区豊洲三丁目1番1号 豊洲IHIビル） \\ E-mail: norihiko_suzuki@ihi.co.jp
}

\begin{abstract}
労働安全衛生規則は, 物体の落下による危険防止に関する規定及び飛来防止設備を規定している. 特 に，建築基準法施行令第136条の5では具体的に規定している。国土交通省の建設工事公衆災害防止対策 要綱土木工事編は, 作業する場所からふ角75度以上の範囲は立入禁止措置等を要請している.すなわち, その範囲外が安全離隔距離と考える。しかし，この距離は国土交通省関東地方整備局企画部技術調查課 に確認の結果根拠が不明であり先行研究が無いことがわかった。本稿は, 建設時の実態に即した規定根 拠を明確にするために実証実験を行い建設工事公衆災害防止対策要綱第101条規定の妥当性及び飛距離 のメカニズムを解明することを目的とした，その結果，落下物が自由落下をする場合に足場用幅木に一 度衝突し更に落下を続ける間に足場用幅木が撓み戻ろうとする力及び中栈に衝突し金属性単管の撓みに より押出そうとする力によるダブルトリガー効果が生じることで大きな水平方向速度が生じ一般的には 生じないような飛距離が生じるメカニズムを解明した.
\end{abstract}

Key Words : inclination 75degree, double trigger effect, baseboard for scaffold, accelerator

\section{1. はじめに}

物体の落下による危険の防止に関して労働安全衛 生規則第537条では防網設備を設け, 立入区域を設定 する等危険防止の措置をとることになっている。一 方，物体の飛来による危険の防止に関して労働安全 衛生規則第538条では「作業者が危険な場合は, 飛来 防止設備を設け，保護具を使用すること．」1)と定め られている．特に，建築物の高さが $7 \mathrm{~m}$ 以上ある場合 に建築物から作業区域と一般共用区域の境界までの 距離が5m以内の場合は, 建築基準法施行令第136条 の5において落下物防止適用区域となっている. ${ }^{2) さ ~}$ らに, 国土交通省の「建設工事公衆災害防止対策要 綱土木工事編」では, 第101条に落下物に対する防護 規定があり，「施工者は，地上4メートル以上の場所 で作業する場合において，作業する場所からふ角75 度以上のところに一般の交通その他の用に供されて いる場所があるときは, 作業する場所の周囲その他 危害防止上必要な部分を仮材等をもって覆う等落下
物による危害を防止するための必要な施設を設けな ければならない。

なお, 地上4メートル以下の場所で作業する場合に おいても危害を生じるおそれがあるときは，必要な 施設を設けなければならない.」3)とある。（下線筆 者ら）狭義的に考えれば国土交通省に関わる建設工 事のみに適用されると考えられるが，広義として考 えれば建設物の外面に落下防止措置が施されていな い場合の安全離隔距離の指針と考えることができる.

そこで，筆者らはなぜ作業する場所からふ角75度 （下線筆者ら）と規定されたのかを, 国土交通省関 東地方整備局企画部技術調整課技術開発係に確認し たところ，「高さ4mにおいて，防護対策の境界と一 般共用区域・規制区域の境界をその真下の同位置に するよりも安全側を考慮し, 外側へずらした（1m程 度）結果と考えられますが，時期が古く，当時の検 討資料等は見つかりませんでした。もしかしたら， 当時の検討委員会の中で議論して決めたものと想定 されます.」との回答を得た。 
さらに, 本規定に関する先行研究を調査したが存 在しないことが分かった.

したがって，本稿は，建設時の実態に即した場合 の規定根拠を明確にするために実証実験を行い第 101条規定の妥当性及び飛距離の一つのメカニズム を解明することを目的とする.

なお，本稿の落下防止措置は，単管足場パイプに よる中栈，手摺及び幅木のみとする.

\section{2. 自由落下及びその後の衝突方法の検討}

落下物が離れた位置に飛来するためには，自由落 下による運動エネルギーが水平方向の運動エネルギ 一に変換される必要がある. その変換は落下物が何 らかの物体に衝突することで成されるが，落下物と 非衝突物の摩擦や変形によりエネルギーが消費され るため, 自由落下による運動エネルギーの一部が水 平方向の運動エネルギーに変換されることになる.

本稿で考える自由落下物体は，プラント工事等で 使用される鋼製吊りピースを考えた．現場工事では 仮設材料として多く用いられているものである.

本稿では，平成27年度に生じた落下物による労働 災害事例（地上 $44 \mathrm{~m}$ の高さから $7.6 \mathrm{~kg}$ の吊りピースが 落下し水平距離 $10 \mathrm{~m}$ 程度にいた作業員に衝突）を参 考にして，実験条件（災害事例之同一の落体の質量 及び寸法とし，落下高さのみ変更した。）を決めた. なお，本実験を実施するに当たり軽量物(200g)を用 いて 44mの高さから落下試験を実施しているが水平 距離は10mには届かなかった。したがって，実機同 等の飛来物を用いてその飛来・落下メカニズムを解 明することは，国土交通省の「建設工事公衆災害防 止対策要綱土木工事編」では, 第101条の一根拠とな り得ると考えた。

吊りピースの形状は，溶接で取付ける辺の反対側 にシャックル等を通寸穴に沿って丸く仕上げた前方 後円の形をしているのが一般的である.

重量は7.6 kg, 長辺 $275 \mathrm{~mm}$, 短辺 $150 \mathrm{~mm}$ 及び厚さ 28mmである。（図-1参照）

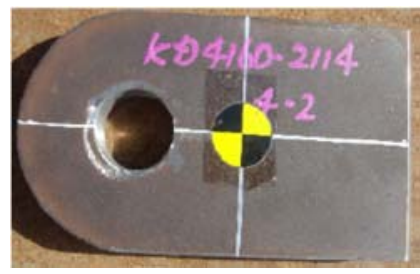

図-1 吊りピース

注記

1．ピースの中心にあるマークは重心を示す．
吊りピースが落下した場合に何に衝突して水平方 向エネルギーに変換されたかである，落下現場には 鋼製足場板を用いた幅木があったのでこれらを与条 件とする．アルミ製梯子もあったが実験の結果から 本稿では省略する。

作業員が，吊りピースを持って取付位置に保持し ていた時に何らかの拍子に手を放したことが自明な ので，どちらかの手を先に離した場合及び同時に両 手を離した場合による吊りピースの傾斜角を変数と する.

\section{3. 実験概要}

\section{（1）実験設備}

本稿で用いた実験設備は，実際に労働災害が発生 した状況と同一にするために，当時の状況を再現し た．ただし，高さに関しては実験設備での再現が困 難なため吊りピースから地盤面までの高さを $3.5 \mathrm{~m}$ と した。（図-2参照）

吊ピースが落下する際の飛距離は，足場から飛び 出す際の水平方向速度により決定される. 前述の労 働災害事例の場合，作業床高さ $41.2 \mathrm{~m}$ (吊ピース取付 高さ44m)の足場から吊ピースが自由落下した場合 に地上に衝突するまでの時間は3秒, 足場枠端部から 被災者までの水平距離は約9mであるため, 被災者ま で吊ピースが到達する場合に必要な水平方向速度は 3m/sである。

吊りピース取付位置は，実際の状況を再現するた めに取付屋根を傾斜させ，作業床を上層階と下層階 の2段階とし状況を忠実に再現した。（図-3参照)

上層階・下層階の足場に用いた幅木は, 足場板 (鋼

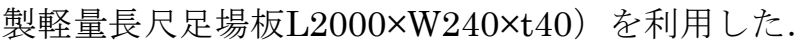
下層階の中栈は，作業床面より高さ450mmに設置し た。（図-4参照）吊りピースは，落下条件を可能な 限り一定とするため，任意の角度で電磁石により固 定し，スイッチにより自由落下できるようにした。

(図-5参照)また, 実験用足場の図面を図-6に示す.

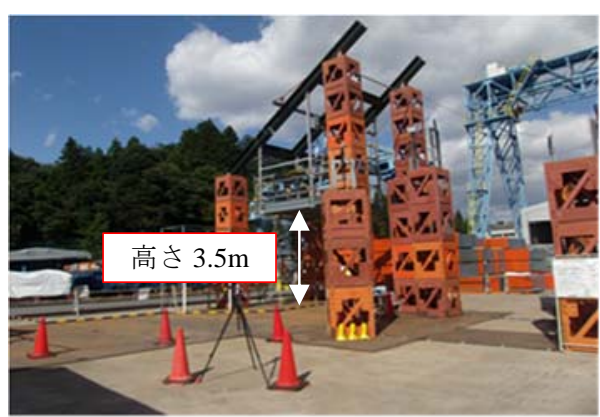

図-2 実験用設備全景 


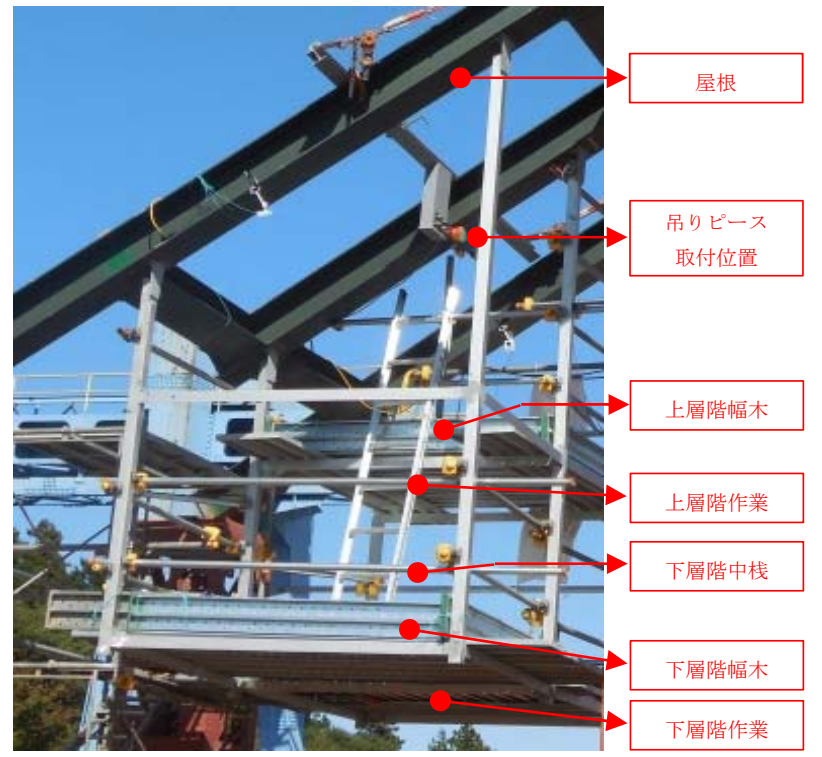

図-3 実験用足場板詳細

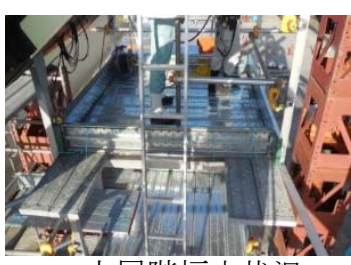

a.上層階幅木状況

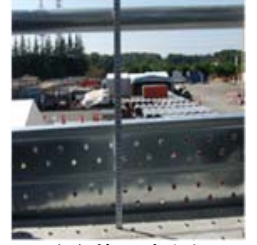

b.下層階の幅木及び 中栈状況

図-4 足場の幅木取付状況

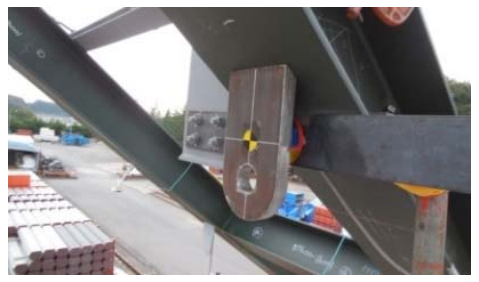

図-5 吊りピース取付状況
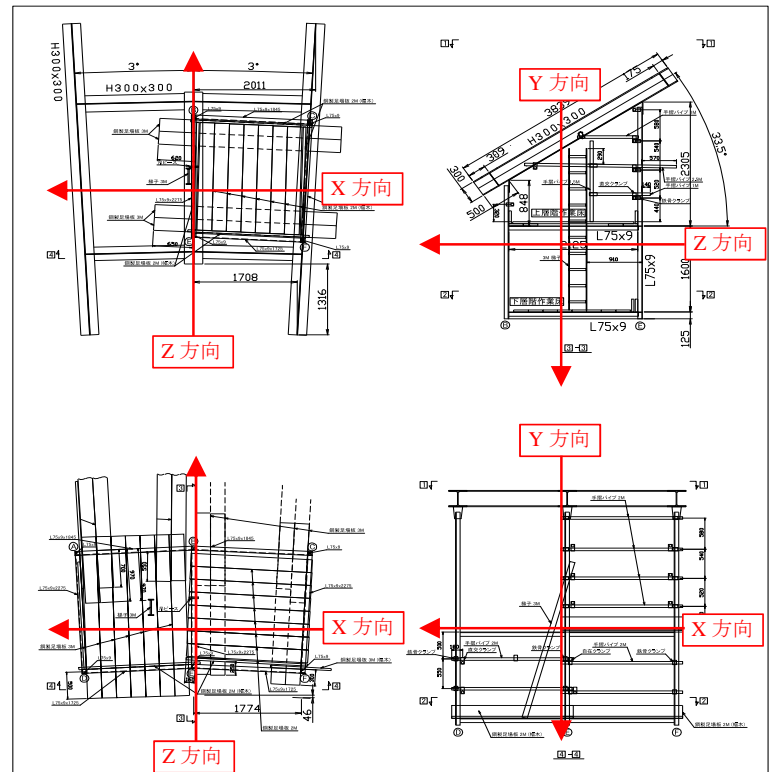

図-6 実験用足場の図面

\section{（2）吊りピースの落下角度と方向の定義}

作業員が両手で吊りピースを抱え上げた後, どち らの手から離すかは不明である。したがって，吊り ピースが自由落下寸るにあたっては，鉛直方向にそ のまま落下する場合と，角度を持って落下する場合 を想定した．検討するにあたっては，吊ピースの長 軸が水平と成す角を条件として，幅木に対する衝突 角度を90度，120度，60度とした．90度は両手を同時 に放した場合、120度は左手を先に放した場合、60 度は右手を先に離した場合に相当する。(図-7参照) 以降，吊ピースが飛び出す方向を正として水平方向 をX方向，鉛直方向をY方向，幅木の長軸方向をZ方 向とする。（図-6, 図-7参照)

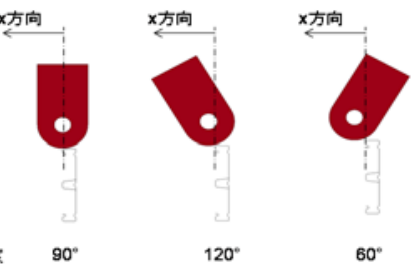

図-7 吊りピースが上段幅木に当衝突する時の傾斜

\section{（3）計測方法}

吊ピースの落下速度を計測するために高速度カメ ラを2台用いた. 自由落下開始から上層階の幅木に衝 突し下層階作業床までの記録を高速度カメラ（モ） クロ) Photron SA5 1300K-M3, 1000fps, 1024x1024, 撮 影時間21.94sを用いた。下層階足場以降地上に到達 するまでを高速度カメラ（カラー） Photron SA5 1300K-C2，1000fps，1024x1024，撮影時間10.92sを用 いた.

\section{4. 実験結果}

吊ピースが足場を飛び出して地上まで落下したケ 一スについて，実験結果の一覧を表-1に示す.

表-1 実験結果

\begin{tabular}{|c|c|c|c|c|}
\hline \multirow[b]{2}{*}{ No. } & \multirow[b]{2}{*}{$\begin{array}{c}\text { 落下角度 } \\
(\mathrm{deg})\end{array}$} & \multicolumn{2}{|c|}{ 水平方向速度 } & \multirow[b]{2}{*}{$\begin{array}{c}\text { 幅木衝突後の } \\
\text { 吊ピースの挙動 }\end{array}$} \\
\hline & & $\begin{array}{c}\text { 上層階幅木 } \\
\text { 衝突後 } \\
(\mathrm{m} / \mathrm{s})\end{array}$ & $\begin{array}{c}\text { 足場枠から } \\
\text { 飛び出した速度 } \\
(\mathrm{m} / \mathrm{s})\end{array}$ & \\
\hline 1 & 92 & 1.9 & 1.6 & 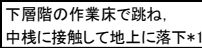 \\
\hline 2 & 91 & 1.8 & 0.6 & 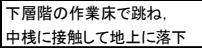 \\
\hline 3 & 95 & 1.9 & 1.9 & 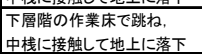 \\
\hline 4 & 117 & 1.9 & 0.8 & 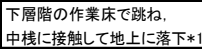 \\
\hline 5 & 116 & 2.0 & 1.3 & 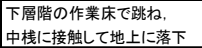 \\
\hline 6 & 123 & 1.7 & 1.2 & 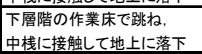 \\
\hline 7 & 60 & 2.6 & 2.4 & 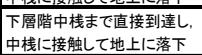 \\
\hline 8 & 59 & 2.7 & 1.9 & 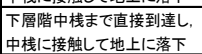 \\
\hline 9 & 59 & 2.8 & 3.3 & 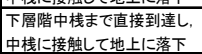 \\
\hline
\end{tabular}

注記 *1は吊ピース自由落下スタート位置が他よりも 390mm低い 
吊ピースが下層階の足場枠を飛び出して地上まで 落下したケースでは, 上層階の幅木への衝突から直 接地上に落下したものは無く, 吊ピースは幅木衝突 後に, (1)下層階の作業床で跳ね, 中栈に接触して地 上に落下寸る場合, (2)中栈まで直接到達し, 中栈に 接触して地上に落下寸る場合があった。表-1には, 上層階の幅木に衝突した後の水平方向速度と足場枠 を飛び出した後の水平方向速度を示している.

実験の結果，吊ピース落下角度 90 度(鉛直方向落 下)と 120 度では大きな水平方向速度とはならず(1)の 落下パターンであったが，60度の場合には，水平方 向速度が大きくなり (2)のパターンで落下した. 最も 速度が大きかった場合には上層階幅木から中栈まで の落下で得た運動エネルギーが中栈への衝突でさら に水平方向速度成分に変換され, 最終的な水平方向 速度は $3.3 \mathrm{~m} / \mathrm{s}$ となった。この実験により, 落下した 吊ピースが, 労働災害事例の被災者に直接到達し得 る水平方向速度となる可能性があることが確認され た. この場合, 吊ピースが直接的に到達した位置及 び下層階作業床までの高さからふ角を算出すると, その角度が76度となり，国土交通省の「建設工事公 衆災害防止対策要綱土木工事編」第101条に記載され ている作業する場所から尔角75度と近似值となる。

\section{(下線筆者)}

以下に吊ピースの落下角度を変化させた場合にお ける吊ピースの衝突状況を示す. 落下角度 90 度の場 合, 吊ピースの重心と幅木の中央位置を合わせて自 由落下させると, 真上に跳衫返るため水平方向速度 が発生しない. そこで, 吊ピースが厚さ $40 \mathrm{~mm}$ の幅木 の端部に衝突するように $20 \mathrm{~mm} \mathrm{X}$ 方向側にシフトさ せた位置を目標として衝突させた。 その他の角度に おいても吊ピースのR部が最初に幅木の端に接触す る位置となるようにX方向位置を調整した。

（1）落下角度90度（鉛直方向）の場合

吊りピースが落下し，幅木に衝突すると吊ピース のR部分で滑り落ち（図-8），下層階の作業床に落 下して跳ね上がる挙動となった。幅木衝突後の速度 は最大 $1.9 \mathrm{~m} / \mathrm{s}$ であった。

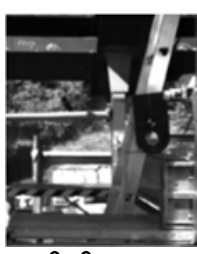

$+0.0 \mathrm{sec}$

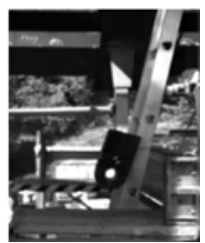

$+0.1 \mathrm{sec}$

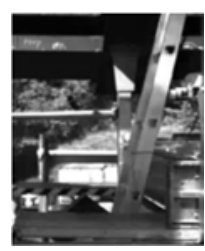

$+0.2 \mathrm{sec}$
図-8 落下角度90度の場合

（2）落下角度120度の場合

吊りピースが落下し，幅木に衝突すると吊ピース
の重心が幅木位置よりX方向前方にあるために，反 時計回りに回転しながら下層階の作業床に落下した

(図-9）。幅木衝突後の速度は最大 $2.0 \mathrm{~m} / \mathrm{s}$ であった。

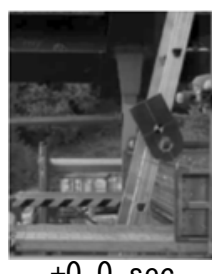

$+0.0 \mathrm{sec}$

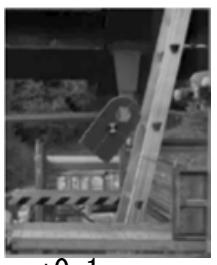

$+0.1 \mathrm{sec}$

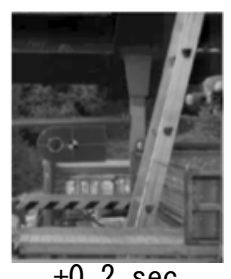

$+0.2 \mathrm{sec}$
図-9 落下角度 120 度の場合

（3）落下角度60度の場合

吊りピースが落下し，幅木に衝突すると幅木が衝 突により一度一X方向に撓む. その後, 幅木が撓ん だ状態から復元し，吊りピースが再衝突することで 吊りピースが $+\mathrm{X}$ 方向に吅き出されることが高速度 カメラの画像より確認できた。このことにより，そ の他の落下角度と比較して, 吊ピースが大きな水平 方向速度を得た（図-10）。幅木衝突後の水平方向速 度は最大 $2.8 \mathrm{~m} / \mathrm{s}$ となり, さらに中栈衝突時に $3.3 \mathrm{~m} / \mathrm{s}$ となった。

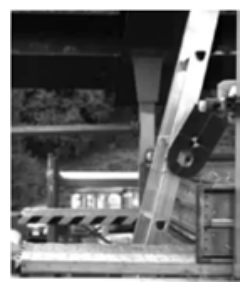

$+0.0 \mathrm{sec}$

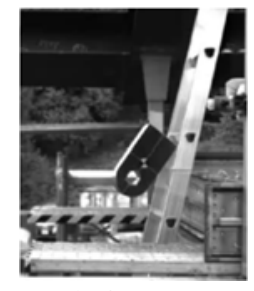

$+0.1 \mathrm{sec}$

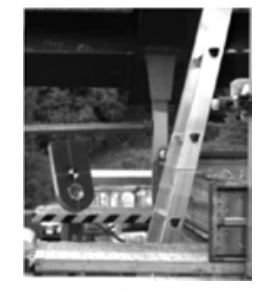

$+0.2 \mathrm{sec}$ a. 上層階の幅木への衝突後の吊ピースの挙動

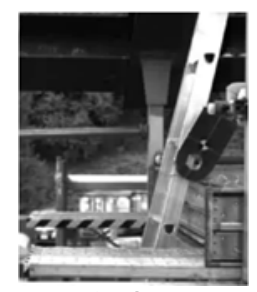

1 回目の衝突+0. $0 \mathrm{sec}$

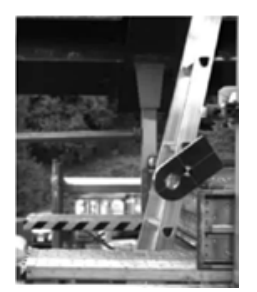

2 回目衝突 $+0.028 \mathrm{sec}$

b. 衝突状況の詳細

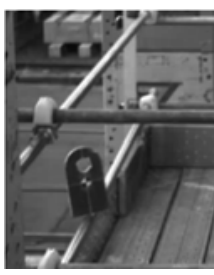

$+0.0 \sec ^{* 2}$

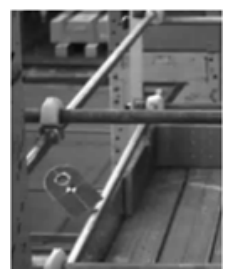

$+0.03 \mathrm{sec}$

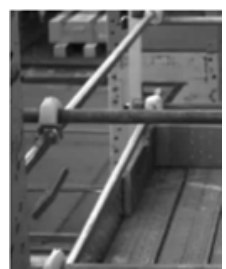

$+0.06 \mathrm{sec}$
注記 *2は上層階幅木衝突から+0.618secで下層 階中栈に衝突した映像である

C. 下層階中栈衝突状況

図-10 落下角度60度の場合 
次に飛来距離を示す. 実験結果のうち地盤まで飛 来したものを“○”で表し，各“○”を吊ピース取 付高さ44mに置き換えたものを“○”で表す.また， 被災者の位置を“”表すと図 - 11の通りとなっ た。これらにより，飛来方向は概ね災害時の方向と 正しく飛来距離も災害時よりも遠方 $(11.4 \mathrm{~m})$ に飛ぶ 場合もあることがわかった。

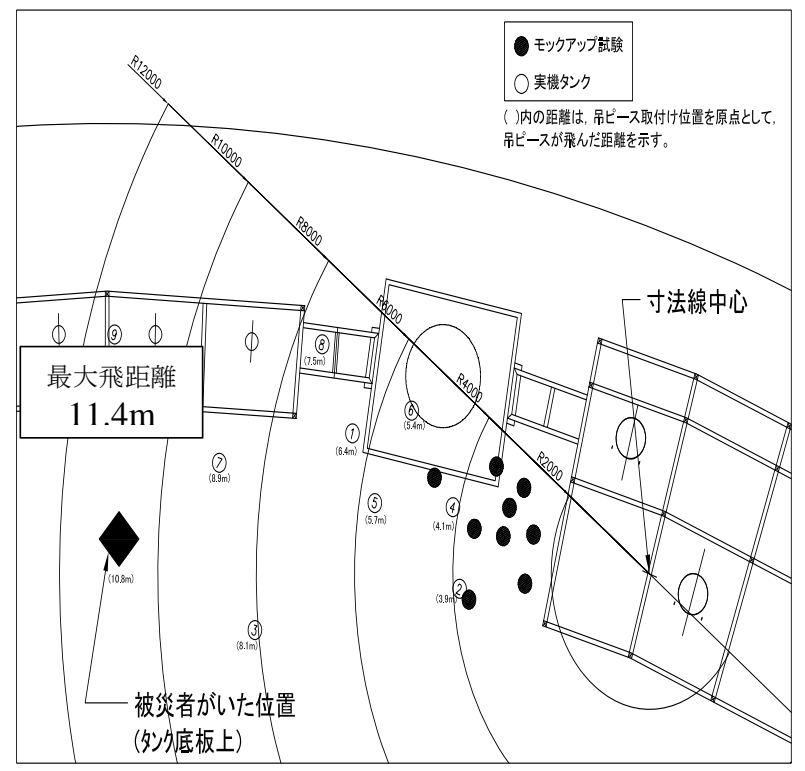

図-11 飛来距離と飛来方向

\section{5. 検討}

実験による吊ピースの落下角度は90度, 120度及び 60度の3ケースであるが, 落下角度の水平方向速度に 対する感度を確認するため上段幅木への吊ピース衝 突を対象とした解析を衝撃・構造解析ソフトウェア LS-DYNAを用いて実施した. 実験時の吊ピースと幅 木の位置関係を図-12に，吊ピースと幅木の材質と寸 法を表-2に, 解析モデルを図-13に示す. なお, 幅木 の中央に設置されていた梯子は省略した。幅木の端 部は，カバーがあり剛性が大きいため，端部の節点 を剛結し，断面形状不変とした。また，図-13左側の 幅木端部は留め金との接触により動きが制限されて いた位置はX方向変位を拘束した，幅木を番線で巻 き付けて固定した位置は，吊ピースの衝突による変 形で番線上部の拘束が緩むことが高速度カメラ画像 から確認されたため, 幅木下部のX方向変位の拘束 でモデル化した。 また，計算時間短縮のため吊ピー スの自由落下の計算は省略し, 衝突直前位置の吊ピ 一スに対して, 落下高さ1215mmから自由落下した場 合の速度を初速度として与えた。

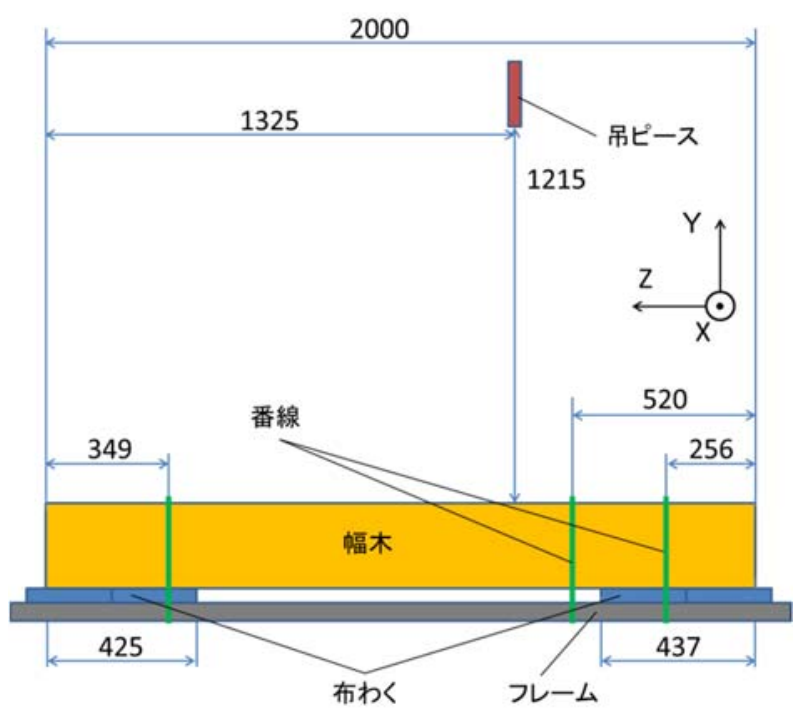

図-12 吊ピースと幅木の位置関係

\begin{tabular}{|l|l|l|}
\multicolumn{2}{c}{ 表-2 } & 部材寸法 \\
\hline & 材質 & 寸法 $(\mathrm{mm})$ \\
\hline 吊ピース & 鋼 & $\mathrm{L} 275 \times$ W150 x T28mm \\
\hline 幅木 & 鋼 & L2000 x W240 x T40mm \\
\hline
\end{tabular}

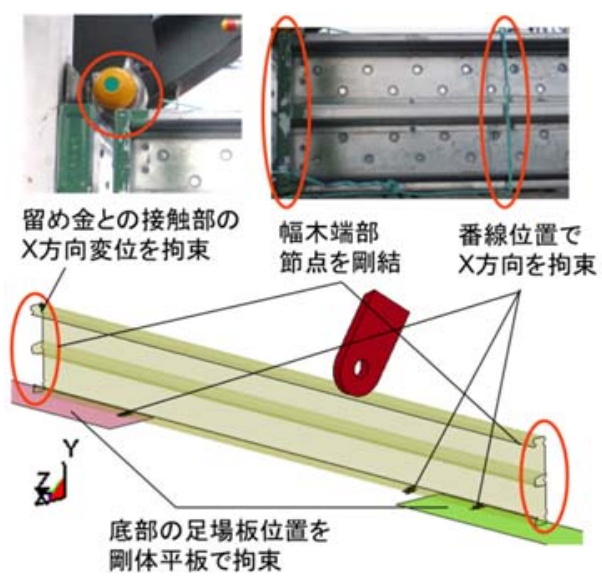

図-13 解析モデル

図-14は, 落下角度と水平速度の関係について解析 結果及び実験結果を比較したものである。また，幅 木衝突時の水平方向速度の変化を図-15に示す.衝突

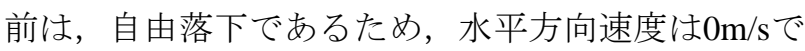
ある. 図-14より，吊ピースの落下角度が大きい条件 では，解析結果と実験結果の差がやや大きい,

しかし，全体的な傾向は，解析結果により捉えら れた。水平方向速度が大きくなる落下角度 60 度付近 に着目すると, 吊ピースの落下角度が多少変化して も，実験と同程度の水平方向速度が吊ピースに発生 すると考えられ，吊ピースが被災者位置にまで到達 する可能性があることがわかる。

また，図-15により，落下角度が90度及び120度の 場合には，吊ピースと幅木の衝突は1回であった。 
一方，60度の場合には，実験と同様に2回にわたっ て吊ピースが幅木に衝突し, 2 回目の衝突によってよ り大きな水平方向速度が吊ピースに発生しているこ とがわかる.したがって, 吊ピースが1度衝突した幅 木に対し，幅木が撓んだ状態から復元しようとする 時に再び吊りピースに再衝突することで吊ピースに 対して比較的大きな水平方向速度を与えるメカニズ ムがあることを解析結果からも確認できた.

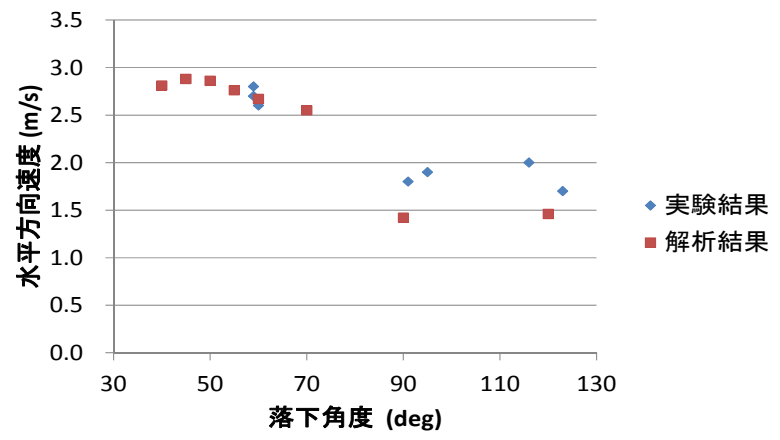

図-14 解析結果と実験結果の比較

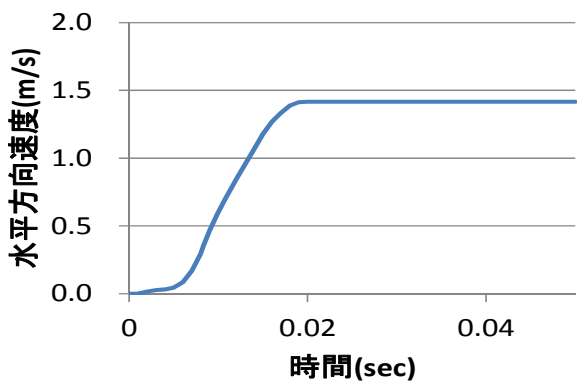

a. 落下角度 $90^{\circ}$

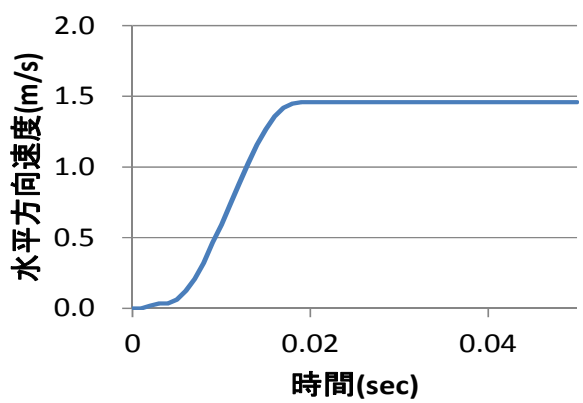

b. 落下角度 $120^{\circ}$

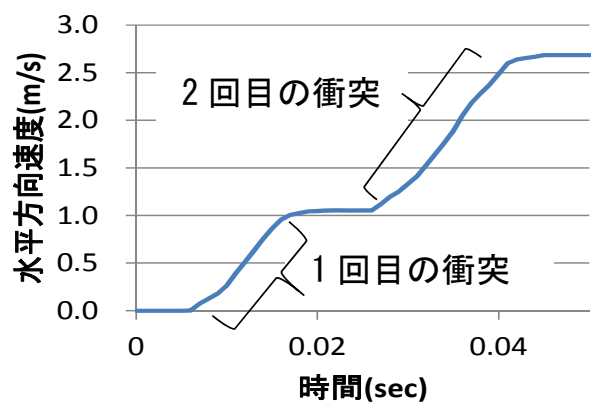

c. 落下角度 $60^{\circ}$

図-15 吊ピースと幅木の衝突による水平方向速度の変化

\section{6. 考察}

実験により，吊ピースが落下した場合に，上層階 の幅木への2段階の衝突による水平方向速度の増加, 下層階の中栈への衝突によるさらなる水平方向速度 の増加といった複数の要因が重なることで離隔角度 （ふ角75度）から求められる離隔距離とほぼ同等の 距離まで落下物が到達する可能性があることがわか った.

本稿では吊ピースを対象としたが，吊ピースのよ うに落下時に幅木を撓ませるだけの初期エネルギー を持っている物体であれば，同様のメカニズムで飛 距離が大きくなることが考えられる.

このように，複数の要因が重なることで落下物の 飛距離が大きくなり得る.

したがって，落下物が足場から飛び出さないよう にメッシュシート又はネット等で落下防止対策及び 墜落防止対策を実施することが重要であると考えら れる。

\section{7. 結論}

吊りピースが，60度方向に傾斜して自由落下する と現場で多用されている鋼製足場板を用いた幅木及 び番線による固定では十分にふ角75度の方向に飛来 する。

したがって，飛来させないためには次の方法によ り落下防止を考慮する必要がある。

（1）メッシュシートにより足場全体を覆う

（2）ネットで作業床から手摺までを覆う

なお，労働安全衛生法第563条の改正により（1） に関しては改正例として示されている4).

メッシュシート等で周囲を覆うことができない場 合は,

（３）落下高さ（m）×tan15を安全離隔距離とし て確保することを考慮する。

\section{参考文献}

1) 厚生労働省,労働安全衛生規則

2) 国土交通省,建築基準法施行令

3) 国土交通省,建設工事公衆災害防止対策要綱土木工事編

4) 厚生労働省,基発0331第9号参考 3 説明資料

http://www. mh1w. go. jp/file/06-Seisaku jouhou-11300000-R oudouki junkyokuanzeneiseibu/0000081487.pdf

(2016. 7. 8受付) 


\title{
A STUDY ON THE SAFETY SEPARATION DISTANCE AGAINST FALLING OBJECTS AT THE TIME OF CONSTRUCTION
}

\author{
Takahisa YAMADA, Shinya FUKUSHIGE, Michitaka FURIKOMA \\ and Norihiko SUZUKI
}

\begin{abstract}
Labor safety and health regulations include provisions on preventing danger due to falling objects, and prescribe equipment to prevent objects from flying in. In particular, specific regulations are set forth in Article 136, Paragraph 5 of Enforcement Orders for the Building Standards Act. The Guidelines on Measures to Prevent Public Disasters in Construction Work (Public Works Volume) of the Ministry of Land, Infrastructure, Transport and Tourism require measures such as prohibiting entry over a range of 75 degrees or more of elevation from the location where work is done. In other words, the area outside that range is regarded as a safe separation distance. However, this distance was checked with the Technology Investigation Section, Planning Department, Kanto Regional Development Bureau, Ministry of Land, Infrastructure, Transport and Tourism, and, as a result, it was found that the grounds for the distance are unclear, and there is no prior research. The purposes of this paper were to carry out demonstration experiments to clarify grounds for provisions suited to the actual situation during construction, and thereby show the validity of the provisions in Article 101 of the Guidelines on Measures to Prevent Public Disasters from Construction Work, and elucidate the mechanisms of flying distance. The results clarified the following mechanism: When an object falls freely, a double-trigger effect may occur due to collision once with the scaffolding baseboard, and while it continues to fall, the force of the baseboard trying to bend back, and due to collision with the crosspiece and the force pushing out due to bending of the single pipe made of metal. In this way, a large horizontal velocity can be produced, resulting in a flying distance greater than that usually encountered.
\end{abstract}

